\section{Plant Density Affects Yield, Yield Components, and Color of Direct-seeded Paprika Pepper}

\author{
J. Cavero ${ }^{1}$ \\ Departamento de Genetica y Produccion Vegetal, Estacion Experimental de \\ Aula Dei (CSIC), Apdo. 202, 50080 Zaragoza, Spain \\ R. Gil Ortega and M. Gutierrez \\ Servicio de Investigacion Agroalimentaria, Apdo. 727, 50080 Zaragoza, Spain
}

Additional index words. Capsicum annuum, pigment, moisture content

\begin{abstract}
Paprika pepper (Capsicum annuum var. annuum L., 'Agridulce SIA') was direct-seeded on raised beds in double rows $0.35 \mathrm{~cm}$ apart. Plants were thinned within the row to establish densities ranging from 13,333 to $>500,000$ plants/ha. Yield of paprika pepper increased as plant density increased, but plant densities $\mathbf{2 0 0 , 0 0 0}$ plants/ha resulted in only small increases in yield. Fruit number and dry fruit weight/plant decreased with increasing plant populations, and weight/fruit decreased slightly. The increase in yield/ha as plant density increased was a result of increased numbers of fruits/ha. Pigment content (ASTA units) declined linearly as plant density increased, whereas moisture content of red fruits at harvest remained unaffected. Plant densities in the range of 150,000 to 200,000 plants/ha were optimal in terms of fruit yield and pigment content.
\end{abstract}

With direct seeding, plant densities can be increased easily with reduced labor and planting costs to improve yields (Stoffella and Bryan, 1988; Sundstrom et al., 1984). The higher costs associated with increases in plant density are primarily due to the increased number of seeds used. Thus, we wished to determine how fruit yield responds to increased plant densities.

Many studies have been published on plant populations for peppers (Batal and Smittle, 1981; Decoteau and Graham, 1994; Jolliffe and Gaye, 1995; Locascio and Stall, 1994; Motsenbocker, 1996; Stoffella and Bryan, 1988; Sundstrom et al., 1984). However, most involved pepper types other than paprika. Moreover, although Kahn et al. (1997) studied the effect of plant density on characteristics of paprika pepper, pigment content, an important quality trait for the paprika industry, was not analyzed.

Most authors reported that peppers produced fewer fruit/plant but more fruits/ha as plant density increased, whereas fruit size was unaffected. Fruit size is less important in terms of fruit quality in paprika peppers than in fresh market or canning peppers because the fruit is ground. However, in paprika peppers that are mechanically harvested, fruit size can affect several processes involved, and, if handharvested, smaller fruits will increase costs.

Received for publication 15 Mar. 2000. Accepted for publication 26 June 2000 . This work was funded by the INIA (project PD94-023-C2-1). The cost of publishing this paper was defrayed in part by the payment of page charges. Under postal regulations, this paper therefore must be hereby marked advertisement solely to indicate this fact.

${ }^{1}$ To whom requests for reprints should be addressed. E-mail address: jcavero@eead.csic.es
Reports about the effect of plant density on yield do not agree on an optimum plant density because this is influenced by the growing system, including the method of establishment (transplanting or direct seeding), the number of rows/bed and the in-row plant spacing, as well as other factors, such as fertility or cultivar traits. Many studies have indicated a linear increase in fruit yield as plant density increased (Decoteau and Graham, 1994; Jolliffe and Gaye, 1995; Motsenbocker, 1996; Stoffella and Bryan, 1988), but plant densities were not totally explored, probably because the planting technique [transplanting, except in the work of Stoffella and Bryan (1988), where plug-mix seeding was used] limited the range of densities. However, this is not a limitation in direct-seeded peppers. The objective of this research was to determine the influence of plant density of direct-seeded paprika pepper on yield, yield components, and paprika color.

\section{Materials and Methods}

Field experiments were conducted during 1996 and 1997 at the Ejea Experimental Farm, Zaragoza, Spain. The soil was a silty clay loam $(45.1 \%$ sand, $27.2 \%$ silt, $27.7 \%$ clay $)$ with $3.71 \%$ organic matter and a $\mathrm{pH}$ of 8.1 . Fertilization consisted of a broadcast, preplantincorporated application of $12 \mathrm{~N}-5.2 \mathrm{P}-14.1 \mathrm{~K}-$ $1.2 \mathrm{Mg}$ at $320 \mathrm{~kg} \cdot \mathrm{ha}^{-1}$ in both years and one topdressing at first bloom of $15 \mathrm{~N}-2.2 \mathrm{P}-16.6 \mathrm{~K}-$ $1.2 \mathrm{Mg}$ at $450 \mathrm{~kg} \cdot \mathrm{ha}^{-1}$ in 1996 and $850 \mathrm{~kg} \cdot \mathrm{ha}^{-1}$ in 1997.

Seed of 'Agridulce SIA', an advanced breeding line with an upright growth habit, was used for direct seeding each year. Seeds were treated with tetramethylthiuram disulfide (thiram) at $5 \mathrm{~g} \cdot \mathrm{kg}^{-1}$ before planting, and planted on raised beds on 10 Apr. 1996 and 24
Mar. 1997. Beds were $1 \mathrm{~m}$ wide $\times 20 \mathrm{~cm}$ high, with $1.5 \mathrm{~m}$ between the centers of contiguous beds. Plots were irrigated before seeding such that soils were near field capacity at seeding. Two rows (35 cm apart) were seeded on each bed as described by Cavero et al. (1996). Seeding was performed with a commercial pneumatic seed drill (model SV260; Gaspardo, Pordemone, Italy) modified as described by Cavero et al. (1996). Distance between seeds was $1.1 \mathrm{~cm}$, the closest in-row spacing allowed by the machine used. Clear polyethylene mulch $(15 \mu \mathrm{m}$ thick $\times 1.1 \mathrm{~m}$ wide $)$ was mechanically placed using a plastic layer (Gadea, Tauste, Zaragoza, Spain) to cover the two rows in each bed. When the soil temperature under the polyethylene mulch was consistently higher than $35^{\circ} \mathrm{C}$, the film was perforated manually. The plastic was removed when the plants had two to three true leaves (10 May 1996; 28 Apr. 1997).

Plants were hand-thinned to the desired in-row spacing on 12 June 1996 and on 17 June 1997 (plants had 10 to 12 leaves), after mechanical reshaping of the beds. Thinning was done at this time to avoid changes in plant density due to mortality during the reshaping of the beds. Plant densities were 13,333, 26,666, 66,666, 133,333, 200,000, $266,666,333,333,400,000,466,666$, and 533,333 plants/ha in 1996, and 20,000, 44,444, $66,666,88,888,111,111,148,148,190,476$, $266,666,333,333,444,444$, and 533,333 plants/ha in 1997. The design was a randomized complete block with four replications each year. The experimental unit consisted of one raised bed $2 \mathrm{~m}$ (1996) or $3 \mathrm{~m}$ long (1997), with two rows/bed.

Weeds were controlled with $N^{\prime}-(3,4-$ dichlorophenyl)- $N$-methoxy- $N$-methylurea (linuron) at $0.17 \mathrm{~kg} \cdot \mathrm{ha}^{-1}$ (1996) and 2-[(2chlorophenyl)methyl]-4,4-dimethyl-3isoxazolidone (clomazone) at $0.27 \mathrm{~kg} \cdot \mathrm{ha}^{-1}$ (1997) applied after sowing, and with mechanical cultivation and manual hoeing after removal of the polyethylene mulch. Furrow irrigation was used to irrigate the plots every 7 to $14 \mathrm{~d}$. Irrigation was stopped when $20 \%$ of the fruits reached maturity (red color). Defoliation was promoted with an application of magnesium chlorate $(57.4 \%)$ at $5 \mathrm{~L} \cdot \mathrm{ha}^{-1}$ on 20 Sept. 1996 and 29 Sept. 1997.

A single harvest was made on the central 1-m section of each plot on 10 Nov. 1996 and 29 Oct. 1997. Plants were counted in this section and marketable fruit were harvested. Fruit that were orange, green, bleached, or filled with fungi were not collected. Marketable fruit were leathery, partially dried, and red. Fruit were counted and weighed in the field, and samples of 100 fruit/plot were dried at $55{ }^{\circ} \mathrm{C}$ in ventilated ovens until constant weight and weighed again to determine moisture content. A sample of 30 fruit/ plot was used for pigment content determination following the ASTA 20.1 method (American Spice Trade Association, 1968) with a spectrophotometer (U-2000; Hitachi, Tokyo).

Data were analyzed by regression analysis with STATGRAPHICS (1988). The yield/ area : plant density relationship was asymp- 
totic, as indicated by several authors (Holliday, 1960; Shinozaki and Kira, 1956; Willey and Heath, 1969). Thus, the asymptotic equation of Holliday (1960) was used:

$$
y=a * x /(1+a * b * x)
$$

where $y$ is the paprika yield (dry weight in $\left.\mathrm{kg} \cdot \mathrm{ha}^{-1}\right), x$ is the plant density (plants/ha), $a$ represents the apparent maximum yield/plant and $1 / b$ indicates the maximum yield/area (Fig. 1). However, instead of using $b$ we used $c(=1 / b)$. Then the equation used was:

$$
y=a * x /[1+(a * x / c)]
$$

Accordingly, the yield/plant : plant density relationship was described by:

$$
w=a /[1+(a * x / c)]
$$

where $w$ is the yield/plant $\left(\mathrm{kg} \cdot \mathrm{ha}^{-1}\right)$.

The number of fruit/plant : plant density relationship was similar in its form to the yield/plant : plant density relationship; therefore, Eq. 2 was used. The number of fruit/area : plant density relationship was similar in its form to the yield/area : plant density relationship, so Eq. 1 was used. Nonlinear regression was used for all these variables. Linear regression was used to analyze the weight/fruit : plant density and the paprika color : plant density relationships. Regression analysis was applied to each year's data. For those variables that did not differ significantly at $P \leq 0.05$ between years, data were pooled and regression results are shown for the 2 years combined.

Plant counts at harvest revealed differences in some plots from the initial plant densities established at thinning. Data from plots where the deviation from the initial plant density was $>15 \%$ were discarded (eight plots in 1996 and seven in 1997), to avoid nondirect plant density effects on yield, such as selfthinning (Firbank and Watkinson, 1990). Thus, the available plots for the study were reduced by $20 \%$ and $16 \%$ in 1996 and 1997, respectively. However, the large number of treatments and replicates allowed statistical analysis.

\section{Results}

Paprika yield/ha and per plant. Paprika yield/ha increased with plant density, especially at densities below 50,000 plants/ha, but densities $>200,000$ plants/ha resulted in only small increases in yield (Fig. 1). Differences between years in the apparent maximum yield/plant $(a)$ were nonsignificant, but the maximum yield $(c)$ differed between years, varying between 4021 (1996) and 3160 (1997) $\mathrm{kg} \cdot \mathrm{ha}^{-1}$. The yield/plant decreased as plant density increased (Fig. 1), especially at densities $<100,000$ plants/ha.

Yield components. The number of fruits/ plant decreased as plant density increased (Fig. 2A), particularly at densities $<100,000$ plants/ ha. The dry weight/fruit decreased only slightly as plant density increased (Fig. 2B), but the regression was significant $(P<0.0001)$. Differences between years were nonsignificant for either variable.
The relationship between the number of fruits/ha and plant density did not differ between years. The number of fruits increased with plant density up to 200,000 plants/ha (Fig. 2C); further increases in plant density had little effect.

Color. The pigment content (ASTA units) fell linearly as plant density increased (Fig. 3). The reduction was significantly higher in 1996 than in 1997, as indicated by the greater slope of the regression line. The reduction in pigment color as plant density increased could not be explained by fruit maturity, as no relationship could be established between water content of fruit at harvest and plant density (data not shown). Only red fruits were harvested, as indicated above.

\section{Discussion}

Both the number of fruits/ha and paprika yield increased as plant density increased from 13,333 to 200,000 plants/ha, while dry weight/ fruit was almost unaffected. Although the fruit number/plant decreased as plant density increased from 13,333 to $>500,000$ plants/ha, the number of fruits/ha continued to increase. Similar findings have been reported for other pepper types (Decoteau and Graham, 1994; Jolliffe and Gaye, 1995; Motsenbocker, 1996; Stoffella and Bryan, 1988), and for paprika pepper (Kahn et al., 1997), although these researchers did not test plant populations as high as those in the present study. Fery and Janick (1970) reported similar findings for tomato (Lycopersicon esculentum Mill.).

Motsenbocker (1996) and Jolliffe and Gaye (1995) reported that the leaf area/plant decreased while the leaf area index (LAI) increased as plant density of peppers increased. Plant biomass production/area of land is directly related to radiation interception (Loomis and Connor, 1992). Cebula (1995) and Lorenzo and Castilla (1995) reported higher radiation interception because of higher LAI at higher plant densities, which resulted in higher biomass and pepper fruit yield. This probably explains why paprika yield increased as plant density increased in our studies. Further, solar radiation interception by plants levels off at high LAI. Increases in LAI above a threshold (around 3.5-4 for most crops) do not increase radiation interception (Loomis and Connor, 1992). This explains why increases in plant density above a threshold did not result in increases in fruit number/area of land and in yield. The testing of high pepper populations allowed confirmation of this yield plateau in response to increased plant populations, as suggested by Kahn et al. (1997).

The slight decrease in fruit size (g/fruit) when plant density increased could be relevant for hand harvest, but probably not for mechanical harvest.

The reduction in pigment content (ASTA units) of paprika as plant density increases has not been reported before. Stoffella and Bryan (1988) did not examine pigments, but reported that mature green bell pepper fruit became more yellow during the first harvest as plant population increased. Sundstrom et al. (1984), using once-over harvest, reported that the percentage of red 'Tabasco' pepper fruit increased relative to that of green and orange fruit at higher plant densities, whereas Kahn et al. (1997) reported no such influence. This reduction in pigment content must be taken into account when establishing the optimal plant density for paprika production.

Carotenoid pigments are responsible for pigment color in paprika (Almela et al., 1991; Candela et al., 1984). The decrease in color as

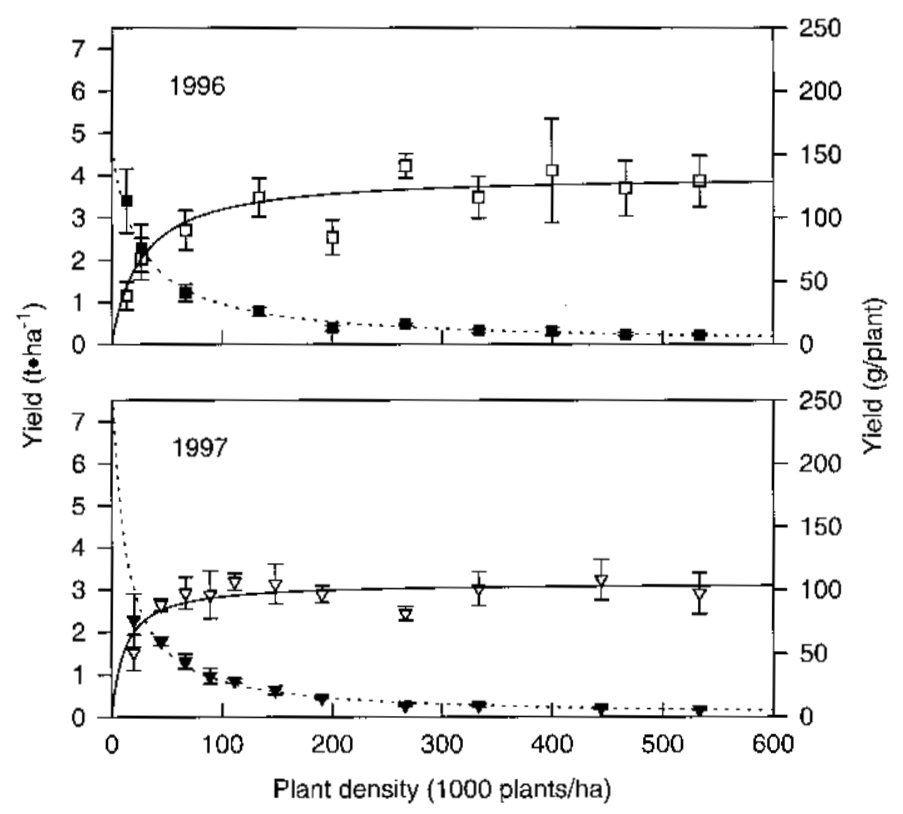

Fig. 1. Plant density effect on paprika yield (dry weight) per ha and per plant in 1996 and 1997. The lines are regression curves for yield/ha (solid line) and yield/plant (dashed line). Error bars represent \pm one standard deviation. For the yield/ha, $y=a * x /[1+(a * x / c)]$. In 1996, $a=0.156 \pm 0.039$, $c=4021 \pm 189, r^{2}=0.72$. In 1997, $a=0.274 \pm 0.093, c=3160 \pm 116, r^{2}=0.63$. The regression curve for the yield/plant is $w=a /[1+(a * x / c)]$. 


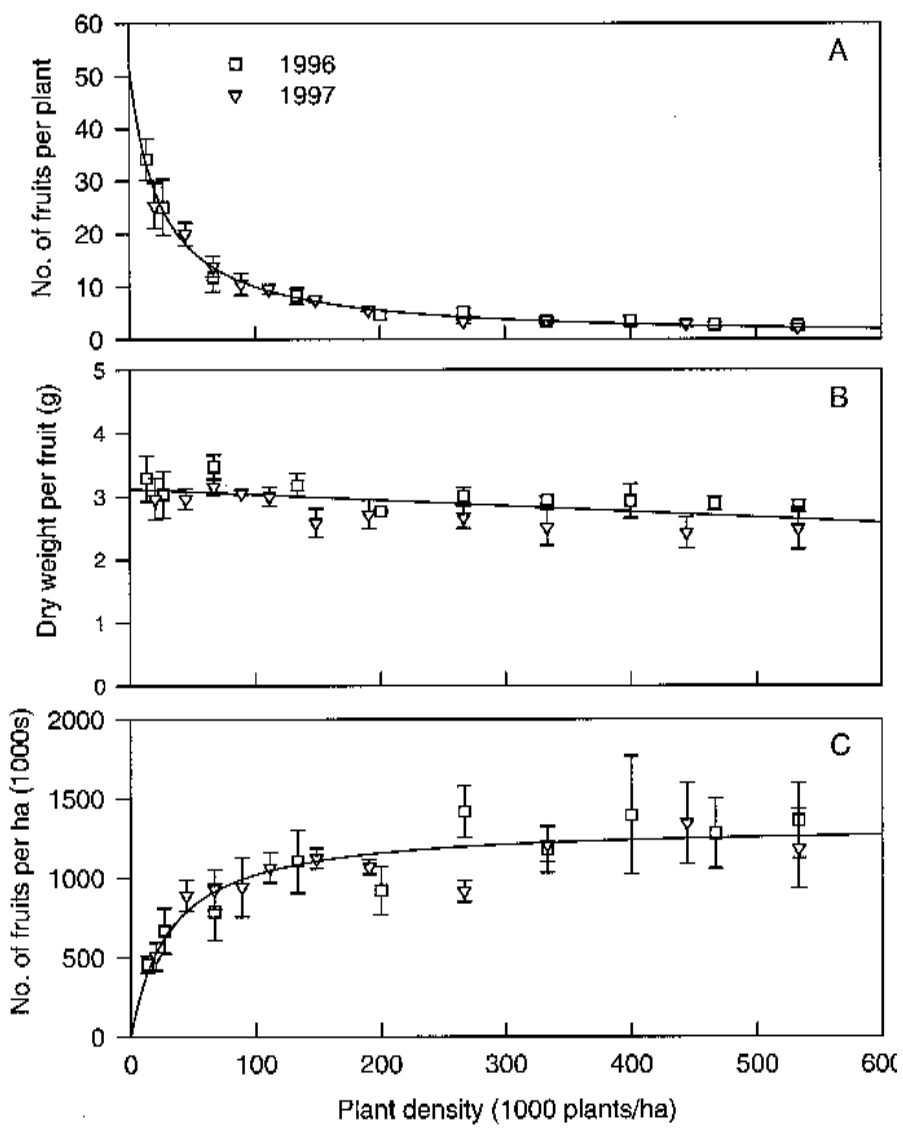

Fig. 2. Plant density effect on the components of yield of paprika pepper. The lines represent the regression curve. Error bars represent \pm one standard deviation. (A) Number of fruits/plant. The regression curve is $y=a /[1+(a * x / c)]$, with $a=51.8 \pm 2.7, c=1,247,920 \pm 59,121, r^{2}=0.96$. (B) Dry weight/fruit. Intercept $=3.13 \pm 0.06$, slope $=-0.00000097 \pm 0.00000019, r^{2}=0.27$, $P<0.0001$. (C) Number of fruits/ha. The regression curve is $y=a * x /[1+(a * x / c)]$, with $a=43.2$ $\pm 6.7, c=1,335,394 \pm 42,923, r^{2}=0.73$.

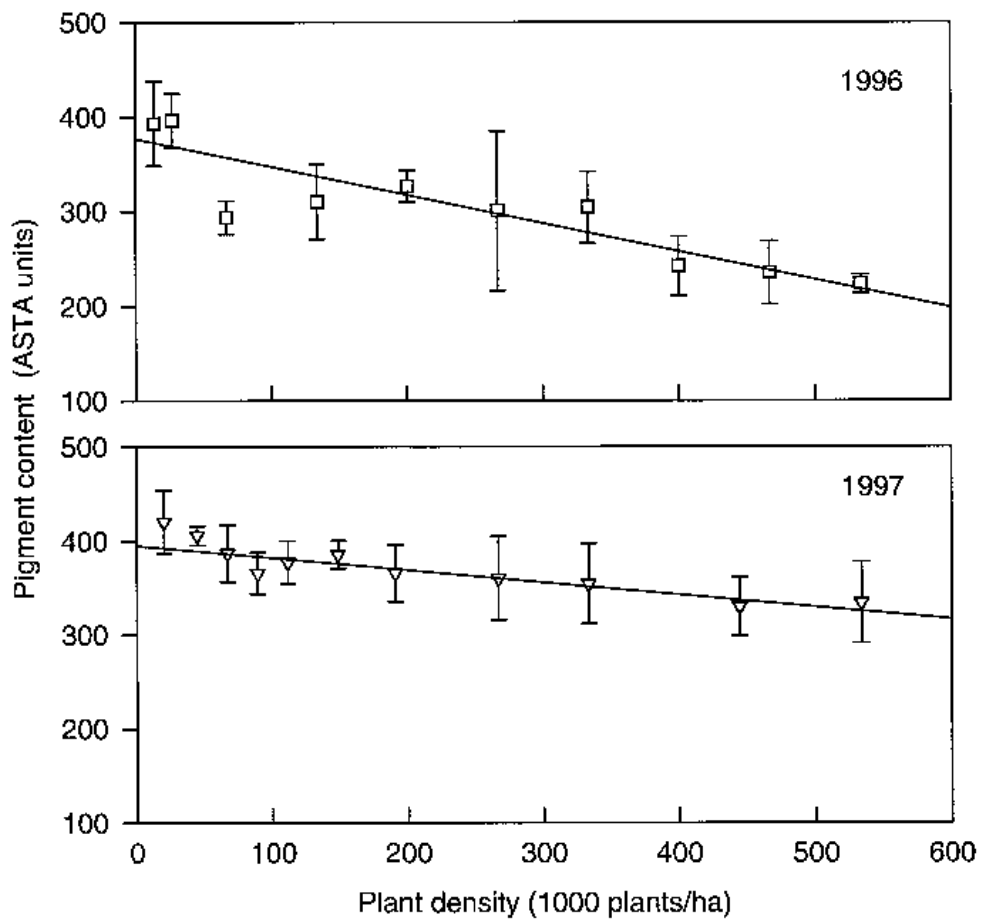

Fig. 3. Plant density effect on the color of paprika fruits in 1996 and 1997. The lines represent the regression curve. Error bars represent \pm one standard deviation. In 1996, intercept $=377 \pm 12$, slope $=-0.000297$ $\pm 0.000039, r^{2}=0.66, P<0.0001$. In 1997, intercept $=395 \pm 9$, slope $=-0.000131 \pm 0.000030, r^{2}=0.34$, $P<0.001$. plant density increased might be related to the higher LAI of the crop at the highest plant densities (Cebula, 1995; Jolliffe and Gaye, 1995; Motsenbocker, 1996), which reduces the interception of radiation by the fruits (Cebula, 1995). Papadopoulos and Ormrod (1988) also reported that penetration of radiation through the canopy decreased as plant density increased in tomato. Reduced interception of radiation could reduce fruit pigment content because a direct relationship has been found between light interception and carotenoid content in peppers (Minguez et al., 1994) and tomatoes (Raymundo et al., 1976). Rylski and Spigelman (1986) also observed that shading delayed the development of red color in pepper. In addition, light quality is modified under a plant canopy; the red : far red ratio decreases as shading increases (Smith, 1982). Papadopoulos and Ormrod (1988) found that the red : far red ratio of the light transmitted through the canopy decreased with increases in tomato plant density. This fact could also contribute to a decrease in pigment color of paprika at higher plant densities because red light induces and far red inhibits carotenoid biosynthesis, as found in tomatoes (Lee et al., 1996; Thomas and Jen, 1975).

Direct seeding of paprika peppers is a relatively new technique in our area. Growers in Spain are paid not only by yield but also by pigment content of dry fruits. Given these growing and marketing conditions, our results indicate that populations in the range of 150,000 to 200,000 plants/ha were optimal in terms of yield, as they were near the yield plateau, and pigment content was still high (>300 ASTA units). Using these plant densities will also help avoid excessive use of seed for stand establishment.

\section{Literature Cited}

Almela, L., J.M. Lopez Roca, M.E. Candela, and M.D. Alcazar. 1991. Carotenoid composition of new cultivars of red pepper for paprika. J. Agr. Food Chem. 39:1606-1609.

American Spice Trade Association. 1968. Official analytical methods, 2nd ed. Englewood Cliffs, N.J.

Batal, K.M. and D.A. Smittle. 1981. Response of bell pepper to irrigation, nitrogen, and plant population. J. Amer. Soc. Hort. Sci. 106:259262.

Candela, M.E., M. Lopez, and F. Sabater. 1984. Carotenoids from Capsicum annиum fruits: Changes during ripening and storage. Biol. Plant. 26:410-414

Cavero, J., R. Gil Ortega, and C. Zaragoza. 1996 Clear plastic mulch improved seedling emergence of direct-seeded pepper. HortScience 31:70-73.

Cebula, S. 1995. Optimization of plant and shoot spacing in greenhouse production of sweet pepper. Acta Hort. 412:321-329.

Decoteau, D.R. and H.A.H. Graham. 1994. Plant spatial arrangement affects growth, yield, and pod distribution of cayenne peppers. HortScience 29:149-151.

Fery, R.L. and J. Janick. 1970. Response of the tomato to population pressure. J. Amer. Soc. Hort. Sci. 95:614-624.

Firbank, L.G. and A.R. Watkinson. 1990. On the effects of competition: From monocultures to 
mixtures, p. 165-192. In: J.B. Grace and D. Tilman (eds.). Perspectives on plant competition. Academic Press, San Diego.

Holliday, R. 1960. Plant population and crop yield. Nature 186:22-24.

Jolliffe, P.A. and M.M. Gaye. 1995. Dynamics of growth and yield component responses of bell peppers (Capsicum annuum L.) to row covers and population density. Scientia Hort. 62:153-164.

Kahn, B.A., J.R. Cooksey, and J.E. Motes. 1997. Within-row spacing effects on traits of importance to mechanical harvest in paprika-type peppers. Scientia Hort. 69:31-39.

Lee, G.H., J.M. Bunn, Y.J. Han, and D.R. Decoteau. 1996. Determination of optimum levels of light irradiation needed to control ripening of tomatoes. Trans. Amer. Soc. Agr. Eng. 39:169-175.

Locascio, S.J. and W.M. Stall. 1994. Bell pepper yield as influenced by plant spacing and row arrangement. J. Amer. Soc. Hort. Sci. 119:899_ 902.

Loomis, R.S. and D.J. Connor. 1992. Crop ecology: Productivity and management in agricultural systems. Cambridge Univ. Press, Cambridge, Mass.

Lorenzo, P. and N. Castilla. 1995. Bell pepper yield response to plant density and radiation in unheated plastic greenhouse. Acta Hort. 412:330 334.

Minguez, M.I., M. Jaren, and J. Garrido. 1994. Competition between the processes of biosynthesis and degradation of carotenoids during the drying of peppers. J. Agr. Food Chem. 42:645-648.

Motsenbocker, C.E. 1996. In-row plant spacing affects growth and yield of pepperoncini pepper. HortScience 31:198-200.

Papadopoulos, A.P. and D.P. Ormrod. 1988. Plant spacing effects on light interception by greenhouse tomatoes. Can. J. Plant Sci. 68:1197-1208.

Raymundo, L.C., C.O. Chichester, and K.L. Simpson. 1976. Light-dependent carotenoid synthesis in the tomato fruit. J. Agr. Food Chem. 24:59-64.

Rylski, I. and M. Spigelman. 1986. Use of shading to control the time of harvest of red-ripe pepper fruits during the winter season in a high-radia- tion desert climate. Scientia Hort., 29:37-45.

Shinozaki, K. and T. Kira. 1956. Intraspecific competition among higher plants. VII. Logistic theory of the C-D effect. J. Inst. Polytech., Osaka City Univ. Ser. D 7:35-72.

Smith H. 1982. Light quality, photoperception, and plant strategy. Annu. Rev. Plant Physiol. 32:481518.

STATGRAPHICS. 1988. User's guide-system. STSC, Rockville, Md.

Stoffella, P.J. and H.H. Bryan. 1988. Plant population influences growth and yields of bell pepper. J. Amer. Soc. Hort. Sci. 113:835-839.

Sundstrom, F.J., C.H. Thomas, R.L. Edwards, and G.R. Baskin. 1984. Influence of $\mathrm{N}$ and plant spacing on mechanically harvested tabasco pepper. J. Amer. Soc. Hort. Sci. 109:642-645.

Thomas, R.L. and J.J. Jen. 1975. Phytochromemediated carotenoids biosynthesis in ripening tomatoes. Plant Physiol. 56:452-453.

Willey, R.W. and S.B. Heath. 1969. The quantitative relationships between plant population and crop yield. Adv. Agron. 21:281-321. 